\title{
PENGARUH PARTISIPASI PENGAWAI TERHADAP KINERJA PELAYANAN DI PT SANG HYANG SERI
}

\author{
UMRAH QALBI P \\ Ilmu Pemerintahan,Fisip,Universitas Muhammadiyah Sidenreng Rappang,Sidrap,Sulawesi Selatan, Indonesia \\ Email: umrahalbip@gmail.com
}

\begin{abstract}
Abstrak
Partisipasi masyarakat merupakan perwujudan dari kesadaran dan kepedulian serta tanggung jawab masyarakat terhadap pentingnya pembangunan yang bertujuan untuk memperbaiki mutu hidup mereka, artinya, melalui partisipasi yang diberikan berarti benarbenar menyadari oleh aparat pemerintah sendiri, tetapi juga menunjuk keterlibatan masyarakat yang akan di perbaiki mutu hidupnya.(Mustanir et al., 2020)
\end{abstract}

\section{PENDAHULUAN}

PT Sang Hyang Seri (persero) berdiri paada tahun 1971 dengan status PERUM(perusahaan umum) di Sukabumi, Subang, Jawa Barat yang mewarisi perkebunan inggris yang bernamaPamanukan and Tjiasen Land yang bergerak dibidang Tapioka dan Rossella. Kemudian melalui proses nasionalisme menjadi menjadi yayasan Pembangunan Daerah Jawa Barat, selanjutnya menjadi LembagaSang Hyang Seri. Pada tahun 1971 melalui peratura pemerintah No. 22 tahun 1971 menjadi PERUM Sang Hyang Seri menjadi core bisnis benih tanaman pangan yang pada tahap awal menitik beratkana pada komoditi benih padi dan beberapa benih palawijaya penting.Pada tahun 1995 status PERUM berubah menjadi PERSERO dengan memperluas core business menjadi benih pertanian dan usaha lain yang langsung menunjang usaha perbenihan yang dapat meningkatkan pendapatan dan 
kinerja perusahaan. Dengan demikian PT SHS merupakan perintis dan pelopor usaha perbenihan di Indonesia serta satu-satunya Badan Usaha Milik Negara (BUMN) yang mempunyai core business perbenihan pertanian. Pada tahun 1997 PT SHS memasuki bisnis benih hortikultura dan pada tahun 2001 mulai mengembangkanbisnis agroinput yang berupa sarana produksi dan agrooutput yang berupa hasil pertanian.Pada tahun 2003 core business dikembangkan dari benih tanaman pangan menjadi benih pertanian dalam arti luas, yaitu meliputi benih tanaman pangan, hortikultura, perkebunan, kehutanan, peternakan dan perikanan. Selain core business, pada tahun 2008 PT SHS dapat pula melakukan kegiatan penunjang core business dan optimalisasi pemanfaatan sumber daya perseroan.

PT Sang Hyang Seri (Persero) merupakan Badan Usaha Milik Negara (BUMN) yang bergerak dalam bidang perbenihan pertanian dituntut untuk menyiapkan benih secara tepat untuk memenuhi kebutuhan konsumen (petani) dan laba yang optimal untuk kelangsungan hidup perusahaan. Oleh karena itu, produktivitas pabrik benih dalam memproduksi benih merupakan salah satu komponen penting dalam menunjang kesinambungan usaha.

\section{B. TINJAUAN PUSTAKA}

Partisipasi masyarakat merupakan perwujudan dari kesadaran dan kepedulian serta tanggung jawab masyarakat terhadap pentingnya pembangunan yang bertujuan untuk memperbaiki mutu hidup mereka, artinya, melalui partisipasi yang diberikan berarti benarbenar menyadari oleh aparat pemerintah sendiri, tetapi juga menunjuk keterlibatan masyarakat yang akan di perbaiki mutu hidupnya.(Mustanir et al., 2020)

Partisipasi dimaknai yaitu "partisipasi masyarakat adalah keikutsertaan masyarakat untuk mengakomodasikan kepentingan mereka dalam proses penyusunan rencana pembangunan" Dari pengertian di atas dapat disimpulkan bahwa partisipasi masyarakat merupakan keterlibatan atau keikutsertaan seseorang masyarakat dalam proses interaksi 
sosial, pengidentifikasian masalah dan potensi yang ada di masyarakat dalam situasi tertentu, baik dalam pengambilan keputusan (solusi) menangani masalah, pelaksanaan upaya mengatasi masalah, dan proses keterlibatan masyarakat di dalam mengevaluasi perubahan yang terjadi. (Mustanir \& Abadi, 2017)

partisipasi adalah pelibatan seseorang atau beberapa orang dalam suatu kegiatan. Keterlibatan dapat berupa keterlibatan mental dan emosi serta fisik dalam menggunakan segala kemampuan yang dimilikinya (berinisiatif) dalam segala kegiatan yang dilaksanakan serta mendukung pencapaian tujuan dan tanggungjawab atas segala keterlibatan. Partisipasi merupakan keterlibatan mental dan emosi dari seseorang di dalam situasi kelompok yang mendorong mereka untuk menyokong kepada pencapaian tujuan kelompok tersebut dan ikut bertanggungjawab terhadap kelompoknya.(Andi Uceng, 2019)

Partisipasi diberi makna sebagai keterlibatan masyarakat dalam proses politik yang seluas-luasnya baik dalam proses pengambilan keputusan dan monitoring kebijakan yang dapat mempengaruhi kehidupan mereka. Berbagai peraturan yang memberikan ruang bagi partisipasi masyarakat secara substantif belum mengatur bagaimana partisipasi masyarakat itu dilaksanakan.(Sapri, S., Mustanir, A., Ibrahim, M., Adnan, A. A., Wirfandi, 2019)

Partisipasi merupakan hal penting yang harus melibatkan masyarakat didalamnya. Seorang ilmuwan yang bernama Keith Davis mengemukakan definisinya tentang partisipasi yang dikutip oleh Santoso Sastropoetro (Sigalingging \& Warjio, 2014) sebagai berikut: "Partisipasi dapat didefinisikan sebagai keterlibatan mental atau pikiran atau moral atau perasaan di dalam situasi kelompok yang mendorong untuk memberikan sumbangan kepada kelompok dalam usaha mencapai tujuan serta turut bertanggung jawab terhadap usaha yang bersangkutan." Berdasarkan pendapat tersebut, maka partisipasi itu tidak berdasarkan keterlibatan secara mental ataupun fisik dalam suatu pekerjaan pembangunan yang telah 
ditetapkan tetapi melainkan menyangkut keterlibatan diri seseorang dalam pembangunan itu sendiri, sehingga akan menimbulkan tanggung jawab dan sumbangan yang besar terhadap kelompoknya. (Irwan et al., 2021)

Partisipasi masyarakat merupakan perwujudan dari kesadaran dan kepedulian serta tanggung jawab masyarakat terhadap pentingnya pembangunan yang bertujuan untuk memperbaiki mutu hidup mereka , artinya, melalui partisipasi yang diberikan berarti benarbenar menyadari bahwa kegiatan pembangunan bukanlah sekedar kewajiban yang harus dilaksanakan oleh (aparat) pemerintah sendiri, tetapi juga menuntuk keterlibatan masyarakat yang akan diperbaiki mutu hidupnya.(Irwan et al., 2019)

Partisipasi masyarakat dapat diartikan sebagai bentuk keterlibatan masyarakat yang memiliki tujuan dan kebutuhan yang sama dalam pengambilan keputusan yang mempengaruhi kehidupannya. Pengertian partisipasi sendiri sangat beragam. Dalam konteks ini, partisipasi di artikan sebagai keterlibatan masyarakat secara aktif dalam setiap tahapan pembangunan mulai dari perencanaan hingga pelaksanaan. Masyarakat tidak lagi menjadi objek dari pembangunan tetapi menjadi subjek pembangunan, dimana masyarakat berperan dalam menyampaikan aspirasi, menentukan pilihan, memanfaatkan peluang dan menyelesaikan masalahnya. (Mustanir, Dema, et al., 2018)

Partisispasi masyarakat adalah keterlibatan masyarakat sesuai dengan hak dan kewajibannya sebagai obyek dan subjek pembangunan, keterlibatan dalam tahap pembangunan dimulai sejak tahap perencanaan sampai pengawasan berikut segala hak dan tanggun jawabnya.(Mustanir, Sellang, et al., 2018) 
Partisipasi memiliki maksud dasar menjadi instrumen yang memberikan peluang yang besar bagi masyarakat untuk dapat berkembang sesuai dengan potensinya, terlibat aktif dalam penyelenggaraan pemerintahan,sehingga pihaknya dapat menikmati mamfaat dari kebijakan, yang dibuat pihak pemerintah.(Latif, Rusdi, et al., 2019)

partisipasi adalah turut sertanya masyarakat pada proses mengidentifikasi potensi dan masalah, ikut sertanya masyarakat dalam pengambilan keputusan, pelaksanaan keputusan, serta keterlibatan dalam proses evaluasi kegiatan. Partisipasi masyarakat menekankan pada "partisipasi" warga secara langsung di lembaga dan dalam proses pemerintahan. Adisasmita dalam solekhan (2014: 141) mengemukakan bahwa partisipasi masyarakat marupakan keterlibatan dalam pelibatan anggota masyarakat dalam pembangunan, mulai dari perencanaan sampai dengan pelaksanaan pada masyarakat lokal.(Latif, Mustanir, et al., 2019)

Pelayanan publik menjadi tolok ukur keberhasilan pelaksanaan tugas dan pengukuran kinerja pemerintah melalui birokrasi. Pelayanan publik sebagai penggerak utama juga dianggap penting oleh semua aktor dari unsur good governance. Para pejabat publik, unsurunsur dalam masyarakat sipil dan dunia usaha sama-sama memiliki kepentingan terhadap perbaikan kinerja pelayanan publik. (Amalia, 2018)

\section{METODE}

Metode yang digunakana dalam partisipasi di rencanakan di lakukan adalah dilaksanakan secara penuh di lapanagan tepatnaya di pt sang hyang seri dengan tetap menjaga protokol kesehatan. Tahapan kegiatan dapat di rini sebagaia berikut:

1. Pemasanngan lebel pada kemasan benih yang nantinya akan di kirim ke kebeberapah daerah. Kegiatan pemsangan lebel ini di maksudkan untuk memberi informasi tentang isi produk yang di beri label tanpa harus membuka kemasan 
2. Pengemasan benih yang di lakukan di gudang sang hyang seri yang bertujuan untuk melindungi benih dari aktot biotik dan abiotik, mempertahankan kemurniaan benih baik seara fisik maunpun genetik serta memudahakan dalam pemyimpanan dan pengakutan

\section{HASI DAN PEMBAHANSAN}

PT Sang Hyang Seri (persero) berdiri paada tahun 1971 dengan status PERUM(perusahaan umum) di dirikan brdasarakan peraturah pemerintah no.22/1997 tanggal 5 mei 1971 dan pada tahun 1981 di dirikan cabang sulawesi selatan (kantor regional VI Tahun 2005) pada tahun 1995 status perum di ubah menjadi persero(PP 18/1995, 28 juni 1995) Di Pt Sang Hyang Memiliki 2 Kantor Yaitu Kantor Regional Kr III Dan Kantor Cabang Sidrap.

Adapaun wilayah kerja kantor regional Kr III

1. Cabang sidrap: dari sulawesi selatan, sulawesi barat, sulawesi tenggara,sulawesi selatan,

2. Cabang maros : sulawei selatan, maluku dan maluku utara

3. Cabang sulawesi tengah : sulawei tengah dan gorontalo, sulawesi utara

4. Cabang kalimantan selatan: kalimatan selatan, kalimantan timur, kalimantan barat, kalimantan tengah, kalimantan utara

5. Satgas papua : papuan dan papua barat 

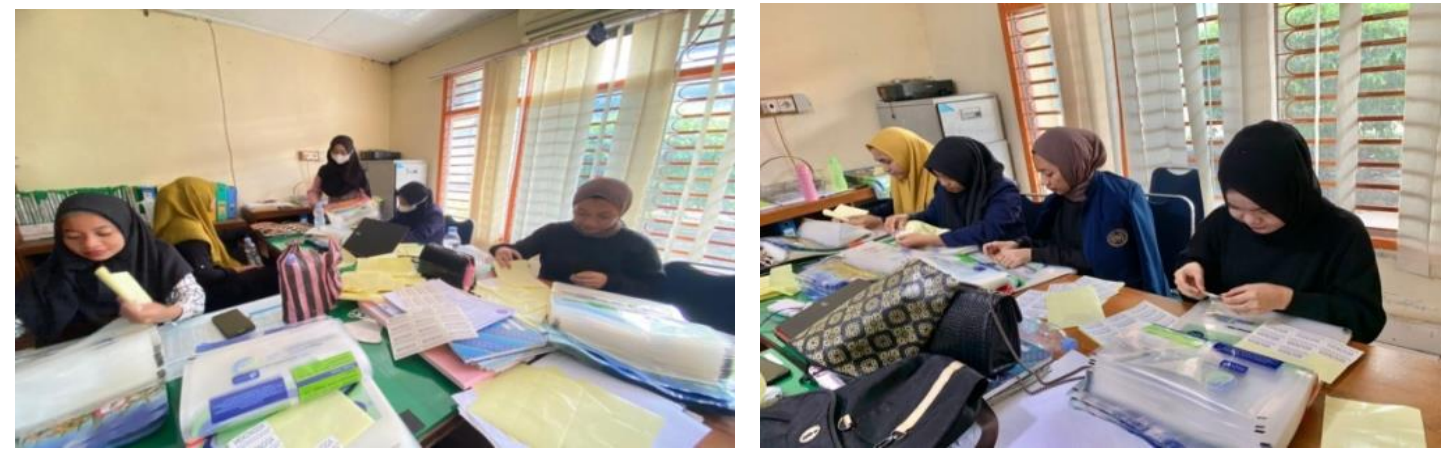

PENGEMASAN LABEL

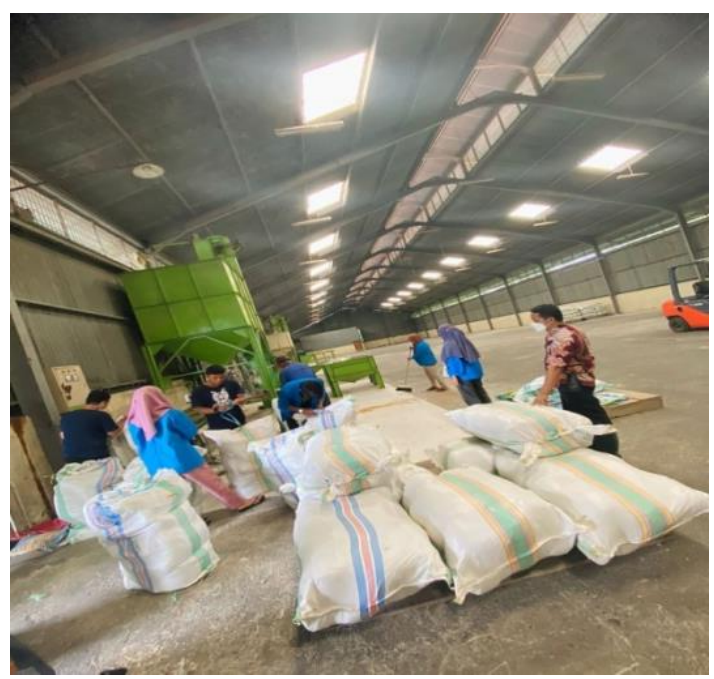

PENGEMASAN BENIH

\section{KESIMPULAN}

PT Sang Hyang Seri (Persero) merupakan Badan Usaha Milik Negara (BUMN) yang bergerak dalam bidang perbenihan pertanian dituntut untuk menyiapkan benih secara tepat untuk memenuhi kebutuhan konsumen (petani) dan laba yang optimal untuk kelangsungan hidup perusahaan. Oleh karena itu, produktivitas pabrik benih dalam memproduksi benih merupakan salah satu komponen penting dalam menunjang kesinambungan usaha.Dari pandangan tersebut dapat disimpulkan dari pendapat pribadi bahwa PT. Sang Hyang Seri merupakan PT Sang Hyang Seri (Persero) disingkat PT SHS (Persero) bergerak di sector 
Pertanian merupakan badan Usaha Milik Negara (BUMN) yang mempunyai tugas pokok untuk memproduksi dan memasarkan benih tanaman pangan. Dimana PT. Sang Hyang Seri bergerak di sector pertanian dengan menghasilkan pangan seperti beras, jagung dan lain-lain, menjadi bagian komoditas ekonomi politik yang berpengaruh besar dalam stabilitas pangan dan politik. Sektor pertanian juga mempunyai peranan yang sangat penting dalam membangun perekonomian nasional termasuk mengoptimalkan sumber daya manusia. 


\section{DAFTAR PUSTAKA}

Amalia, S. (2018). Reformasi Birokrasi 4.0 : Strategi Menghadapi Revolusi Industri 4.0. Jurnal Wacana Kinerja: Kajian Praktis-Akademis Kinerja Dan Administrasi Pelayanan Publik, 21(2), 1-18. https://doi.org/10.31845/jwk.v21i2.133

Andi Uceng, A. A. (2019). Analisis Tingkat Partisipasi Masyarakat Terhadap Pembangunan Sumber Daya Manusia Di Desa Cemba Kecamatan Enrekang Kabupaten Enrekang. MJurnal Moderat, 5(2), 1-17.

Irwan, Latif, A., Sofyan, Mustanir, A., \& Fatimah. (2019). Gaya Kepemimpinan, Kinerja Aparatur Sipil Negara dan Partisipasi Masyarakat Terhadap Pembangunan di Kecamatan Kulo Kabupaten Sidenreng Rappang. Jurnal Moderat, 5(1), 32-43. https://jurnal.unigal.ac.id/index.php/moderat

Irwan, I., Latif, A., \& Mustanir, A. (2021). Pendekatan Partisipatif Dalam Perencanaan Pembangunan di Kabupaten Sidenreng Rappang. GEOGRAPHY Jurnal Kajian, Penelitian Dan Pengembangan Pendidikan, 9(2), 137-151. https://journal.ummat.ac.id/index.php/geography/article/view/5153

Latif, A., Mustanir, A., \& Irwan, I. (2019). Pengaruh Kepemimpinan Terhadap Partisipasi Masyarakat Pada Perencanaan Pembangunan. JAKPP (Jurnal Analisis Kebijakan \& Pelayanan Publik), 144-164. https://doi.org/10.31947/jakpp.v1i2.7977

Latif, A., Rusdi, M., Mustanir, A., \& Sutrisno, M. (2019). Partisipasi Masyarakat Dalam Pembangunan Infrastruktur Di Desa Timoreng Panua Kecamatan Panca Rijang Kabupaten Sidenreng Rappang Dosen Ilmu Pemerintahan Stisip Muhammadiyah Rappang Dosen Ilmu Administrasi Negara Stisip Muhammadiyah Rappang 5). Jurnal MODERAT, 5(1), 1-15. https://jurnal.unigal.ac.id/index.php/moderat/article/view/1898 
Mustanir, A., \& Abadi, P. (2017). Partisipasi Masyarakat Dalam Musyawarah Rencana Pembangunan Di Kelurahan Kanyuara Kecamatan Watang Sidenreng Kabupaten Sidenreng Rappang. Jurnal Politik Profetik, 5(2), 247-261. http://journal.uinalauddin.ac.id/index.php/jpp/article/viewFile/4347/3986

Mustanir, A., Dema, H., Syarifuddin, H., Meity, K., \& Wulandari, S. (2018). Pengaruh Motivasi dan Partisipasi Masyarakat terhadap Pembangunan di Kelurahan Lalebata Kecamatan Panca Rijang Kabupaten Sidenreng Rappang. Jurnal Ilmiah Clean Government (JCG), 2(1), 27-39. http://lonsuit.unismuhluwuk.ac.id/index.php/clean/article/view/212

Mustanir, A., Fitriani, S., Adri, K., Nurnawati, A. A., \& Goso, G. (2020). Sinergitas Peran Pemerintah Desa dan Partisipasi Masyarakat Terhadap Perencanaan Pembangunan di Kabupaten Sidenreng Rappang (The Synergy of Village Government's Role and Community Participation in the Process of Development Planning in Sidenreng Rappang D. Journal of Government Science (GovSci), 2020(2), 84-108.

Mustanir, A., Sellang, K., Ali, A., Madaling, M., \& Mutmainna, M. (2018). Peranan Aparatur Pemerintah Desa Dan Partisipasi Masyarakat Dalam Musyawarah Perencanaan Pembangunan Di Desa Tonrongnge Kecamatan Baranti Kabupaten Sidenreng Rappang. Jurnal Ilmiah Clean Government (JCG), 2(1), 67-84. http://lonsuit.unismuhluwuk.ac.id/index.php/clean/article/view/213

Sapri, S., Mustanir, A., Ibrahim, M., Adnan, A. A., Wirfandi, W. (2019). Peranan Camat dan Partisipasi Masyarakat Dalam Musyawarah Perencanaan Pembangunan Di Kecamatan Enrekang Kabupaten Enrekang. MODERAT: Jurnal Ilmiah Ilmu Pemerintahan, 5(2), 33-48. https://jurnal.unigal.ac.id/index.php/moderat/article/view/2127 
